\title{
THE EFFECT OF PERSONALITY, WORK STRESS AND DECISION MAKING TO ORGANIZATIONAL COMMITMENT AT LIMITED COMPANY OF BHUMYAMCA SEKAWAN IN SOUTH JAKARTA
}

\author{
TUTY SARIWULAN \\ State University of jakarta \\ Tuty.wulan@yahoo.com
}

\begin{abstract}
This title of this research is the influence of employees personality, work stress dan decision making to organizational commitment at Limited Company of Bhumyamca Sekawan in South Jakarta.This study used quantitative approach with survey methods and path analysis technique. The amount of population is 213 employees and using random sampling technique, so the total of sample is 70 employees calculated by slovin formulation Data that used in this research is quantitative data with path analysis methods to find out the path coefficient score. Based on the calculation and hypothesis test, can be concluded as these results: (1) personality has direct positive influence to decision making; (2) work stress has direct positive influence to decision making; (3) personality has direct positive influence to organizational commitment; (4) work stress has direct positive influence to organizational commitment; (5) decision making has direct positive influence to organizational commitment.
\end{abstract}

Keywords: personality, work stress, decision making and organizational commitment

Organizational Commitment is a condition in which employees become highly engaged in the company. Stephen P. Robbins, argues that: Organizational commitment is the degree to which an employee identifies with a particular organization and its goals and wishes to maintain membership in the organization. (Stephen Robbins, 2011). This statement means that: Organizational commitment is the extent to which an employee binds himself to a particular organization with the objectives of the organization, and hopes to maintain membership in the organization. The higher the employees are committed to the company, the employees will work better in their jobs and tasks. Organizational commitment is needed in business competence therefore the company educates employees to commit to what the company aims.

Organizational commitment is influenced by several factors including: Personality or Personality, Job Stress, Decision Making. Personality includes the characteristics or personality traits of a person. According to Stephen P. Robbins: Personality is a dynamic organization that exists within an individual consisting of psychophysical systems that determine a unique adaptation to the environment. Personality is a very important and vital part of a person's life is also very complex where an individual reacts and interacts with other individuals. Robbins also said, there are 5 major personality traits commonly used in organizations in the world of work. Five personality traits are: Extroversion, agreeableness, conscientiousness, emotional stability, openness to experience. (Stephen Robbins, 2004). Personality has internal and external elements. There are 5 dimensions of personality that are conscientiousness, agreeableness, neuroticism (emotional stability, openness to experience.

While Stress Work is one of the problems faced by everyone in everyday life as well as in the work environment. Stress can be interpreted as stress, tension or unpleasant discomfort, there is an imbalance between job demands and individual abilities. Stress of influence is so great for the individual concerned. Fred states that: Stress is usually considered negative. This is thought to be caused by something bad. But there is also the positive side, the pleasant things that are caused by the good things.

In Decision Making employees will choose the right one from several alternatives. The most important factor in making a final decision is to consider the advantages and disadvantages of each alternative. To that end employees need creative, diverse, and inventive arguments. 
Limited Company of Bhumyamca Sekawan is a company engaged in business and property management activities to support the needs of offices, workshops, and warehousing located in Cilandak South Jakarta. This company has modern facilities of international standard with gold / platinum level environmental quality. The mission of this company is to provide the best service by providing modern facilities and environmentally friendly, with employees who are friendly, and sincere.

The company's goal is one of Bhumyamca Sekawan empowering and empowering employees optimally and humanely to be more productive. In order to achieve the objectives, employees are required to commit to the company, in accordance with the requirements when appointment of employees stating that: the employee must have good performance and interpersonal relationships (personality). The company consists of several departments and from the department is further divided into several divisions. The General Department and the Department of Engineering have a high level of stress in which the employee assumes the task or position by taking all the consequences related to the job, working on time, achieving the target within the company.

Based on the statement on the background of the problem it is necessary to carefully the personality, work stress, and decision making that affect organizational commitment in Limited Company of Bhumyamca Sekawan, as well as the title of research are: Influence Personality, Job Stress and Decision Making on Organizational Commitment. Organizational commitment is the degree to which an employee identifies with a particular organization and maintains its membership in the organization (Stephen Robbins, 2010). Commitment is a sense of identification, involvement, and loyalty expressed by an employee toward the company "(John, 2008). "Organizational commitment is defined as the desire on the part of an employee to remain a member of the organization". (Meyer, 1997). Meyer further states: there are 3 types of them: affective commitment, continuance commitment and normative commitment. Personality, Luthans menyatakan sebagai berikut: Personality will mean how people affect others and how they understand view themselves, as well as their pattern of inner and outer measurable traits and the person-situation interaction. Fred Luthan, 2011). Personality a stable set of characteristics and tendencies that determine commonalities and differences in people behavior. (James L, 2012). Robbins et al, said there are five major personality traits: Extroversion, agreeableness, conscientiousness, emotional stability, openness to experience. (Stephen Robbins, 2004). The 5 (five) major are: Extraversion. (like group, firm, and easy to socialize), Agreeableness / easy to get along. (happy to work together, warm, and trusting). Conscientiousness (responsible, orderly, reliable and persistent). Stability of emotion. (tend to be calm, confident and have a firm stand). Open to new things. (open, open tend to be creative, curious).

Stress is dynamic condition in which an individual is confronted with an opportunity, demand, or resource related to what the individual desire and for which the outcome is perceived to the both uncertain and important. (Stephen Robbins, 2011).

Stress is defined as a person's capacity or resources (Colquitt, 2011). Decision making is almost universally defined as choosing between alternatives. (Luthan, 2009). Gibson et al menyatakan bahwa: Decisions means to achieve some result or to solve problem; outcome of a process influenced by many forces (James Gibson,2010). Based on the background and problem formulation, the objectives to be achieved in this research are to know: Direct Personality Influence on Job Stress on Limited Company of Bhumyamca Sekawan Employees in South Jakarta.

1. Direct Personality Influence on Decision Making on Employees Limited Company of Bhumyamca Sekawan in South Jakarta

2. Direct Effect of Job Stress on Decision Making on Employees of Limited Company of Bhumyamca Sekawan in South Jakarta

3. Direct influence of personality on Organizational Commitment to Employees of Limited Company of Bhumyamca Sekawan in South Jakarta.

4. The direct influence of Decision Making on Organizational Commitment on employees of Limited Company of Bhumyamca Sekawan in South Jakarta 
5. Direct influence of work stress on Organizational Commitment to Employees of Limited Company of Bhumyamca Sekawan in South Jakarta.

\section{METHOD}

This research uses quantitative approach, survey method and path analysis technique. The dependent variable is $\mathrm{Y}$ (Organizational Commitment) and the independent variables are: $\mathrm{X} 1$ (personality), X2 (work stress) and X3 (decision-making) variables. The influence between variables was analyzed by path analysis.

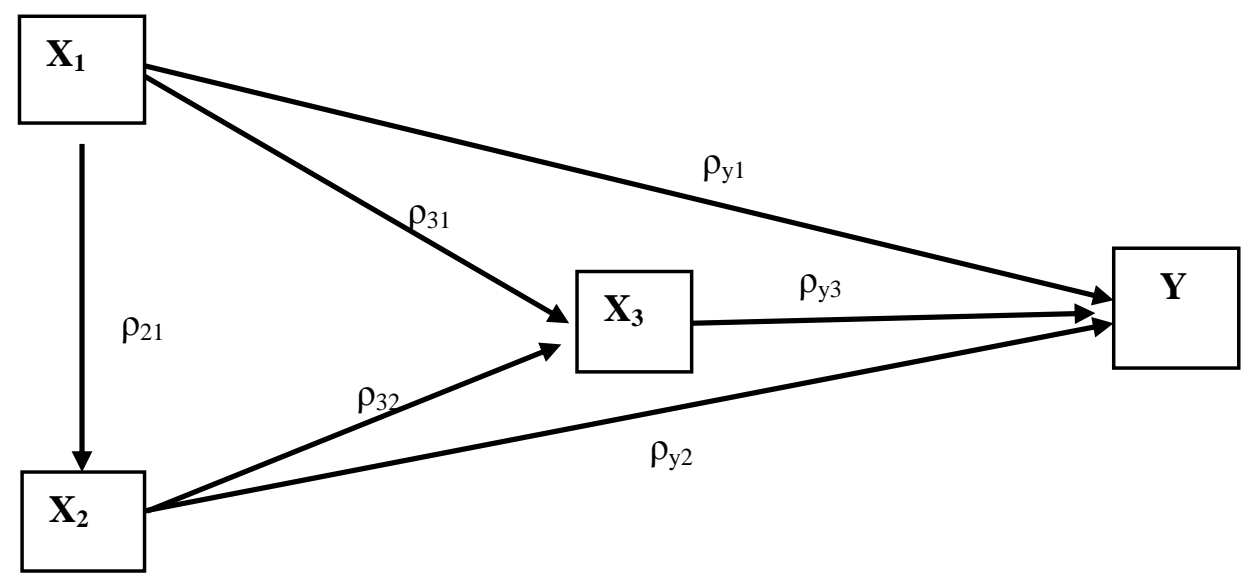

Figure 1. Constellations of Influence between Variables

Information:

$$
\begin{aligned}
& Y=\text { Organizational Commitment } \\
& X 2=\text { Work Stress } \\
& X 1=\text { Personality } \\
& X 3=\text { Decision Making } \\
& \rho=\text { Path coefficient }
\end{aligned}
$$

To find out whether the normal distribution is used Kolmogorov Smirnov test count with the help of SPSS application version 24.

If the calculation result of test value $\mathrm{K}-\mathrm{S}>\alpha(0,05)$ then variable that tested have normal distribution (SPSS output attached). From result of normality test to 4 (four) test result variable can be seen in table below.

Table 1. Calculation Value of Kolmogorov-Smirnov Test

\begin{tabular}{|c|l|c|c|l|}
\hline No. & \multicolumn{1}{|c|}{ Variable } & $\begin{array}{c}\text { The calculation } \\
\text { results }\end{array}$ & Level $\boldsymbol{\alpha}$ & \multicolumn{1}{|c|}{ Conclusion } \\
\hline 1 & Organizational Commitment & 0,200 & 0,05 & Distributed normally \\
\hline 2 & Personality & 0,200 & 0,05 & Distributed normally \\
\hline 3 & Work Stress & 0,191 & 0,05 & Distributed normally \\
\hline 4 & Decision Making & 0,191 & 0,05 & Distributed normally \\
\hline
\end{tabular}

Source: Primary Data processed in 2016

\section{RESULT AND DISCUSSION}

Before testing the hypothesis in path analysis, there are requirements that must be met namely; 1). Samples taken from the population have a normal distribution, 2). Has a linear 
relationship between independent variables with dependent variables, 3). The linear or straight-line relationship is significant.

To test the linear correlation between variables and significant used test criterion by using test of linearity at $5 \%$ significance level $(0,05)$. The test model used is the F test in the ANOVA table. The linearity test is obtained from the line deviation from linearity that is $\mathrm{F}$ count greater than 0.05 . The theory says that if $\mathrm{F}$ count is greater than 0.05 then the relationship of variables is linear. Similarly, the regression equation is obtained from the regression row in the ANOVA table, if the value of $\mathrm{F}$ count and p-value is less than 0.05 ( $F$ count value and p-value <0.05), then the regression line is significant. The results of the linearity test (SPSS output attached) can be seen in the following table.

Table 2. Linearity Test between Variables

\begin{tabular}{|c|c|c|c|c|c|}
\hline \multirow{2}{*}{ No. } & \multirow{2}{*}{ Variable } & \multicolumn{3}{|c|}{ Deviation from Linearity } & \multirow{2}{*}{ Conclusion } \\
\cline { 3 - 5 } & F(ANOVA Table) & Sig (p-value) & $\boldsymbol{\alpha}$ & Linear \\
\hline 1 & $\mathrm{X}_{1}$ to $\mathrm{X}_{2}$ & 0,901 & 0,621 & 0,05 & Linear \\
\hline 2 & $\mathrm{X}_{1}$ to $\mathrm{X}_{3}$ & 0,818 & 0,719 & 0,05 & Linear \\
\hline 3 & $\mathrm{X}_{2}$ to $\mathrm{X}_{3}$ & 0,818 & 0,719 & 0,05 & Linear \\
\hline 4 & $\mathrm{X}_{1}$ to & 0,704 & 0,848 & 0,05 & Linear \\
\hline 5 & $\mathrm{X}_{2}$ to $\mathrm{Y}$ & 1,291 & 0,242 & 0,05 & Linear \\
\hline 6 & $\mathrm{X}_{3}$ to $\mathrm{Y}$ & 0,760 & 0,761 & 0,05 & \\
\hline
\end{tabular}

Source: Primary Data Processed Year 2016

Similarly, the linearity significance test after the comparison between the results of calculations ANOVA with $\alpha(0.05)$ then obtained the results as in table 3 below.

Table 3. Regression Line Significance Test

\begin{tabular}{|c|l|c|c|c|l|}
\hline No. & Variable & Anova $(\mathbf{F})$ & Sig $(\boldsymbol{p}$-value $)$ & $\boldsymbol{\alpha}$ & Hypothesis \\
\hline 1 & $\mathrm{X}_{1}$ to $\mathrm{X}_{2}$ & 0,082 & 0,775 & 0,05 & Not significant \\
\hline 2 & $\mathrm{X}_{1}$ to $\mathrm{X}_{3}$ & 31,080 & 0,000 & 0,05 & Significant \\
\hline 3 & $\mathrm{X}_{2}$ to $\mathrm{X}_{3}$ & 7,573 & 0,007 & 0,05 & Significant \\
\hline 4 & $\mathrm{X}_{1}$ to $\mathrm{Y}$ & 4,245 & 0,043 & 0,05 & Significant \\
\hline 5 & $\mathrm{X}_{2}$ to $\mathrm{Y}$ & 5,474 & 0,022 & 0,05 & Significant \\
\hline 6 & $\mathrm{X}_{3}$ to $\mathrm{Y}$ & 4,649 & 0,035 & 0,05 & Significant \\
\hline
\end{tabular}

Source: Primary Data Processed Year 2016

From result of significance test turns $\mathrm{X} 1$ relationship to $\mathrm{X} 2$ is not significant. Thus the linearity for $\mathrm{X} 1$ against $\mathrm{X} 2$ is not eligible for path hypothesis testing.

After 3 (three) requirements in the analysis are met, where based on SPSS calculation for significance test of regression line between two variables (there is one regression line that is X1 to X2 not qualified). Thus for the next test cannot be calculated path, and for phase test path there are 5 regression lines are analyzed.

The next stage to describe the causal relationship or causal relationship between independent variables with the dependent variable, the researchers used the model of the path diagram. In this study only take into account the direct influence of independent variables on the dependent variable. The magnitude of direct influence of independent variable to dependent variable is expressed by path coefficient with notation $\rho$. The constellation between variables (path diagram) after the conditions are met becomes as follows: 


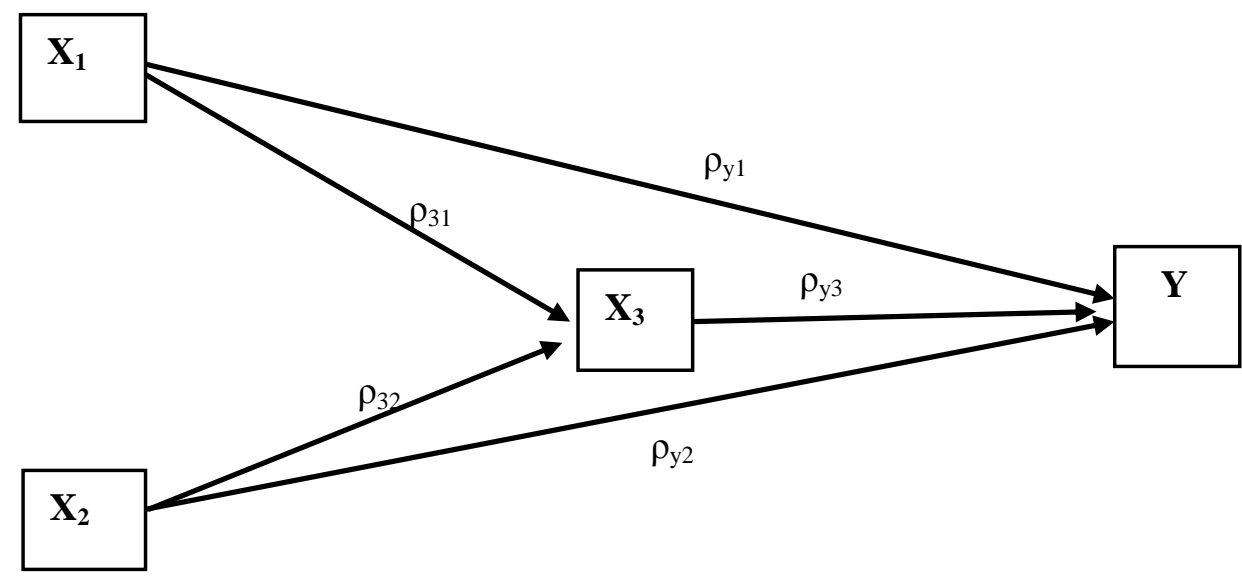

Figure 2. Constellations of Influence between Variables

\section{Hypothesis Testing}

To illustrate the causal relation or causal relationship between independent variables and dependent variable, the researcher uses the path form diagram model. In this study only take into account the direct influence of independent variables on the dependent variable. The magnitude of direct influence of independent variable to dependent variable is expressed by path coefficient with notation $\rho$.

The path coefficient is obtained in the beta column (standardized Coefficients) at the SPSS output. While the hypothesis to be tested is the coefficient of free variable path to the dependent variable. From table Coefficients obtained t-count value and p-value (sig). If the value of t-count $>+/-$ 1.658 at $\alpha=0,05$ or $p$-value (sig) $<0,05$ then t- reject Ho. That is: there is a direct positive influence of independent variables on the dependent variable.

From the calculation and hypothesis test the relationship of the five independent variables to the bound can be seen in the following table.

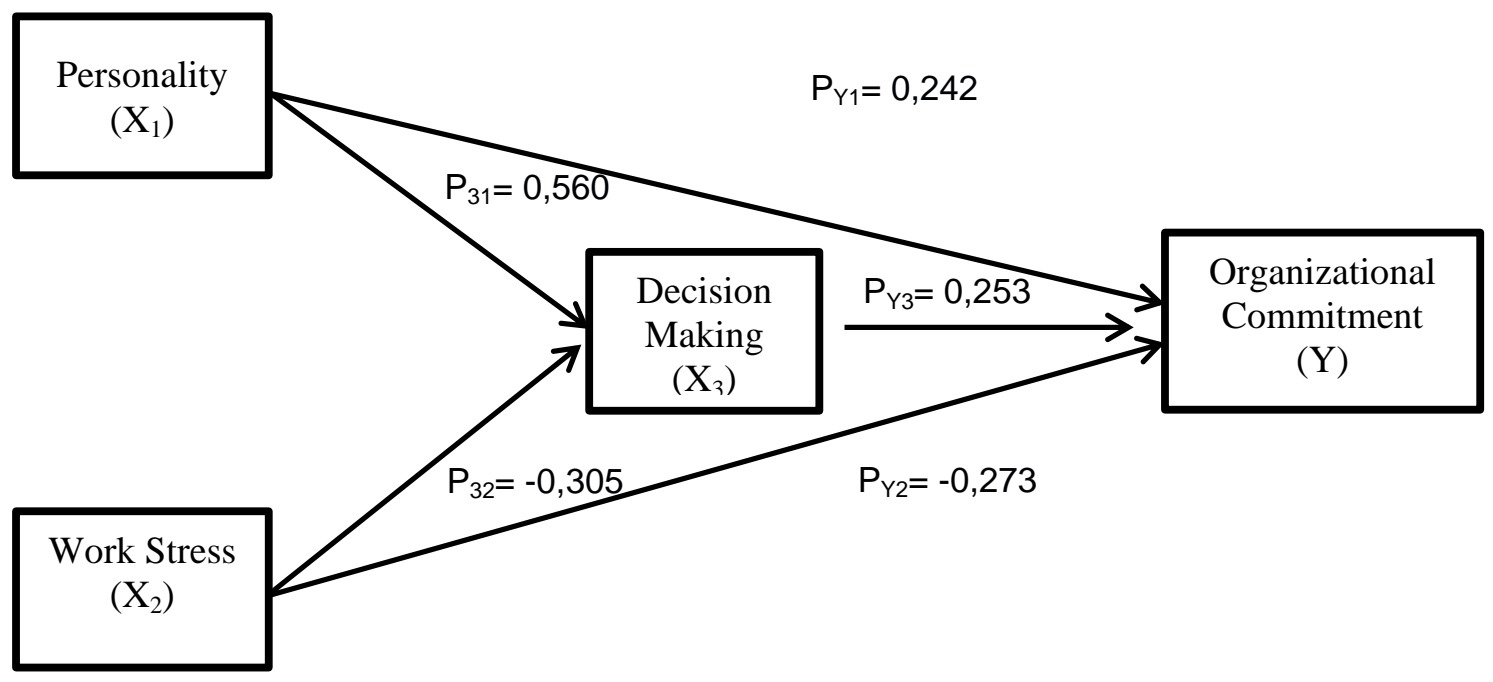

Figure 2. Constellations of Influence between Variables

From the calculation of path analysis can be synthesized that the causal relationship is all significant means that the hypothesis states that there is a direct influence of independent variables on the dependent variable. There are two causal relationships that are very significant meaning with the real level of $0.01(1 \%)$ being in the Ho starting area. While the remaining three causal relationships, significant with a real level of $0.05(5 \%)$. 
For more details below presented recapitulation table results of hypothesis testing calculations.

Table 4. Recapitulation of Hypothesis Testing Results

\begin{tabular}{|c|c|c|c|c|c|}
\hline No & Hypothesis & Statistic test & $\begin{array}{c}\text { Path } \\
\text { Coefficient ( } \rho)\end{array}$ & $t_{\text {-count }}$ & Conclusion \\
\hline 1 & $\begin{array}{l}\text { Personality (X1) has a } \\
\text { direct effect on Decision } \\
\text { Making (X3) }\end{array}$ & $\begin{aligned} \text { Ho }: \beta_{31} \leq 0 \\
\mathrm{H}_{1}: \beta_{31}>0\end{aligned}$ & $\rho_{31}=0,560$ & $5,575 * *$ & Reject $\mathrm{H}_{\mathrm{o}}$ \\
\hline 2 & $\begin{array}{l}\text { Working Stress (X2) has } \\
\text { a direct effect on } \\
\text { Decision Making (X3) }\end{array}$ & $\begin{array}{l}\text { Ho: } \beta_{32} \leq 0 \\
\mathrm{H}_{1}: \beta_{32}>0\end{array}$ & $\rho_{32}=-0,305$ & $-2,752 * *$ & Reject $\mathrm{H}_{\mathrm{o}}$ \\
\hline 3 & $\begin{array}{l}\text { Personality (X1) has a } \\
\text { direct effect on } \\
\text { Organizational } \\
\text { Commitment (Y) }\end{array}$ & $\begin{array}{l}\mathrm{Ho}: \beta_{\mathrm{y} 1} \leq 0 \\
\mathrm{H}_{1}: \beta_{\mathrm{y} 1}>0\end{array}$ & $\rho_{\mathrm{y} 1}=0,242$ & $2,060 *$ & Reject $\mathrm{H}_{\mathrm{o}}$ \\
\hline 4 & $\begin{array}{l}\text { Working Stress (X2) has } \\
\text { a direct effect on } \\
\text { Organizational } \\
\text { Commitment (Y) }\end{array}$ & $\begin{array}{l}\mathrm{Ho}: \beta_{\mathrm{y} 2} \leq 0 \\
\mathrm{H}_{1}: \beta_{\mathrm{y} 2}>0\end{array}$ & $\rho_{\mathrm{y} 2}=-0,273$ & $-2,340^{*}$ & Reject $\mathrm{H}_{\mathrm{o}}$ \\
\hline 5 & $\begin{array}{l}\text { Decision Making (X3) } \\
\text { has a direct effect on } \\
\text { Organizational } \\
\text { Commitment (Y) }\end{array}$ & $\begin{array}{l}\mathrm{Ho}: \beta_{\mathrm{y} 3} \leq 0 \\
\mathrm{H}_{1}: \beta_{\mathrm{y} 3}>0\end{array}$ & $\rho_{\mathrm{y} 3}=0,253$ & $2,156^{*}$ & Reject $\mathrm{H}_{\mathrm{o}}$ \\
\hline
\end{tabular}

* Significant at $\alpha=0.05$ (t-table $=1.658$ and -1.658$)$

** Very significant at $\alpha=0.01(\mathrm{t}$-table $=2.358$ and -2.358$)$

\section{Personality Influence on Decision Making}

Result of analysis test to hypothesis show that there is direct positive influence of Personality to Decision Making. Employees of Limited Company of Bhumyamca in the face of customers or consumer show the nature and characteristics of personality that is: good, cooperative, friendly, polite, calm, assertive, sociable and open. In certain situations or in urgent circumstances can make decisions according to his job, and the decision is the best of some alternative options. Thus the higher the Personality of the employee the Decision Making will be better. This is reinforced by some expert researchers such as: (1). Advisor Budiman, who stated in his research that Personality has a positive and significant impact on the process of Decision Making as a customer. (Arief, 2015). (2) .Kotler mentions that Personality is a part of individual characteristics affecting Decision Making. (3) .Attavia, in his research stated that, the Personality variable that is part of the individual characteristics has the most dominant influence on the Decision Making process. (Aktavia, 2014).

\section{Effect of Job Stress on Decision Making}

Hypothesis testing proves that; There is a direct negative effect of work stress on decision making. Employment of Limited Company of Bhumyamca employees includes conditions where employees perceive role conflicts experienced, employees bear workload of work to be completed on time, pursuing targets primarily in the marketing division, as well as changes in the home environment with the company, and others it is characteristic of stress. 
The burden faced as above leads to lower the desire to make decisions. Actually the decision is taken by knowing the problem solving and should be based on the selection of the best alternative, but in situations experiencing stress the task to be done becomes not maximal.

The theory says that: work stress has an inverse relationship with decision making. The more Stress employees the smaller the decision taken. This is reinforced by researcher Tati Monawaroh in his research states that: Job Stress directly affects negative decision-making. Based on the results of the study can be concluded, that if Stress Work increased it will result in decline in Decision Making. (Tati Munawaroh, 2013).

3. The Effect of Personality on Organizational Commitment

Hypothesis test results indicate that there is a direct positive effect of Personality on Organizational Commitment. In other words, the higher the positive nature of the employee's Personality, the higher the employee is to commit to the company.

From the results of the research, and from the questionnaire filled, the employee has done his best to complete the tasks. Employees never think of being lost to follow-up or leaving the company. Bhumyamca employees feel that they are already a part and have been integrated into the company. This statement is reinforced by the results of the study (1).Dyan Fausiah, in research related to Personality with Organizational Commitment. The results of the analysis show that this Personality has a positive and significant influence on Organizational Commitment. (Diah F, 2013). The same opinion is expressed by (2). Kumar and Bakskhi in Personality or Personality research in relation to Organizational Commitment, indicating that the results of Personality Test against Organizational Commitment of employees, proved to have a significant effect. Personality that is characterized by agreeable is also one of the factors capable of establishing increased Organizational Commitment of employees.

\section{The Effect of Job Stress on Organizational Commitment}

Hypothesis test results in path analysis, it is said that there is a direct negative effect of Work Stress on Organizational Commitment. Based on the results of research and answers filled employees at Limited Company of Bhumyamca, some work, especially in the division of marketing, facilities, cleanliness and security has a strong relationship with Job Stress, among others caused by: demands tasks such as the imperative to make decisions quickly, work, time issues relating to the number of jobs. Theory says that: If the above problem cannot be managed properly it will cause stress. If stress already occurs automatically will decrease Organizational Commitment. This theory is reinforced by several researchers. (1) Moncrief, in his research says there is a significant and negative effect of Work Stress on Organizational Commitment. This is very influential on the continuity of the organization. (Moncrief, 1997). (2) Khatibi, doing the same research related to Work Stress and Organizational Commitment, aims to examine the effect of Job Stress on Organizational Commitment in National Olympic and Paralympic Academy. The variables used are Job Stress, Affective Commitment, Sustainability Commitment, and Normative Commitment. The result shows that job stress has a significant negative effect to (a) Affective Commitment, (b) Stress Work has a significant negative effect on sustainability commitment, and (c) work stress has significant negative effect on normative commitment. (Khatabi, 2009). Similarly, researchers (3) Velnampy and Aravinthan, stated that Job Stress has a significant and negative relationship with Organizational Commitment. In his research revealed that Job Stress has a significant and negative relationship with organizational commitment. (Velnampy, 2013). The next researcher (4) Pool, proves that Job Stress has a direct negative and significant effect with Organizational Commitment. Conflict as a stress-maker has an effect on decreasing Organizational Commitment. (Pool S, 2000). 
5. Effect of Decision Making on Organizational Commitment

Hypothesis test results after tested by using a certain significant level then it is said that: There is a positive direct influence Decision Making on Organizational Commitment to employees of Limited Company of Bhumyamca Sekawan.

From the results of the research and the list of questionnaires that Limited Company of Bhumyamca employees have filled out, it is written that employees are involved and given an opportunity in Decision Making within the division where employees are placed. Decision-making is done by way of deliberation with the work team of a division, so that decisions taken can reduce the risk. The ideas and thoughts of employees are appreciated by the leadership. Deliberation is a learning for employees in making decisions, so there will be a sense of trust, so that the increased Organizational Commitment.

As stated by: (1). Hadi Gunawan, in his research there is a positive direct influence of Decision Making on Organizational Commitment, this research was conducted on Structural Officer of Echelon IV Director General of Correctional Ministry of Justice and Human Rights. The implication of this research is the effort in improving decision making of echelon IV officials can be done through the improvement of organizational commitment. (Hadi Gunawan, 2013).

Colquitt says that one of the factors that can influence the realization of an Organizational Commitment is a sense of trust by giving an opportunity to act, communicating by involving in deliberation, fostering social relationships. (Colquitt, 2011).

\section{CONCLUSION}

Based on the hypothesis test obtained the following results: Personality has a direct positive effect on Decision Making. This shows that improving Personality will result in better Decision Making, Job Stress directly negative influence on Decision Making. This shows that the level of Job Stress has an inverse relationship with Decision Making. If Job Stress is high then result in Decision Making will decrease, Personality has a direct positive effect on Organizational Commitment, indicating that improvements in Personality lead to an increase in Organizational Commitment, Work Stress directly negative effect on Organizational Commitment, it shows that if the level of Job Stress is high, it will affect the decrease of Organizational Commitment, and Decision Making has a direct positive effect on Organizational Commitment, indicating that improvements in Decision Making affect the increase of organizational commitment.

\section{REFERENCE}

Aktavia. (2014). The influence of individual characteristics on the decision-making process of the limited liability company of Bank Muamalat Makassar branch. Journal, Makasar.

Colquitt, Jason A., Jeffery A. Lepine, dan Michael J. Wesson. (2011). Organizational Behavior Improving Performance and Commitmen in the Workplace. New York: McGraw Hill/Irwin.

Dyan Fausiah. (2013). The Influence of Personality and Interpersonal Communication Against Organizational Commitment to Government Institutions. Journal, Jakarta.

Fred Luthans, Jonathan P. Doh. (2009). International Management. NY: McGraw-Hill Companies Inc.

Fred Luthans. (2011). Organizational Behavior. New York : McGraw-Hill.

Gibson, James L., John M. Ivancevich, James H. Donelly, Jr., and Robert Konopaske. (2006). Organizations Behavior Structure Processes. New York: McGraw-Hill Companies, Inc.

Hadi Gunawan. (2013). Directorate General of Corrections of the Ministry of Justice and Human Rights Republic of Indonesia 2nd International Seminar on Quality and Affordable Education (ISQAE). 
Ivancevich, John M., Robert Konopaske, dan Michael T. Matteson. (2008). Organizational Behavior and Management, Eight Edition. New York: Mc Graw-Hill Companies Inc.

Gibson, James L., John M. Ivancevich, James H. Donelly, dan Robert Konopaske. (2012). Organizations Behavior, Structure, Processes, 14th edition. New York: MvGraw-Hill.

Khatibi, A. H. Asadi and M. Hamidi. (2009). The Relationship Between Job Stress and Organizational Commitment in National Olympic and Paralympic Academy. (World Journal of Sport Sciences, Vol. 2, No. 4, PP 272-278 ISSN 2078-4724).

Meyer, John P., dan Natalie J. Allen. (1997). Commitment in the worplace theory research and application. California : Sage Publications.

Moncrief, W.C., Emin Babakus, Cravens, D.W., Johnston, M. (1997 ). Examining The Antecedents and Consequences of Salesperson Job Stress. (Eurupeon Journal of Marketing, vol.31 no.11/12).

Pool, S . W. (2000). Organizational Culture and its relationship between Job Tension in measuring outcomes Among Business Executive. The Journal Of Mangement Development, Vol 19. No. 1.

Robbins, Stephen P. (2004). Organizational Behavior. Upper Saddle River: Prentice-Hall.

Robbins, Stephen P, dan Timothi A. Judge. (2011). Organizational Behavior Fourteenth Edition. New Jersey : Pearson Education Inc.

Tati Munawaroh. (2013). The objective this research is to verifly that: Stress effects on comitment organization, stress effects on decision making, decision making effects on commitment organization. (Epigram, Vol. 10 No. 2 October)

Velnampy, T and Aravinthan. S. A. (2013). Occupational Stress and Organizational Commitment in Private Banks: A Sri Lankan Experience. (European Journal of Business and Management. Vol.5, No.7). ISSN 2222- 1905. 